$\begin{array}{ll}\text { Abstracta Iranica } & \begin{array}{l}\text { Abstracta Iranica } \\ \text { Revue bibliographique pour le domaine irano-aryen }\end{array} \\ & \text { Volume } \mathbf{2 4} \text { | } \mathbf{2 0 0 3} \\ \text { Comptes rendus des publications de } \mathbf{2 0 0 1}\end{array}$

\title{
Le traité de l'esprit saint de Rûzbehân de Shîrâz. Paris, Cerf, 2001, 362 p.
}

Pierre Lory

\section{(2) OpenEdition}

Journals

Édition électronique

URL : http://journals.openedition.org/abstractairanica/34555

DOI : 10.4000/abstractairanica.34555

ISSN : 1961-960X

Éditeur :

CNRS (UMR 7528 Mondes iraniens et indiens), Éditions de l'IFRI

\section{Édition imprimée}

Date de publication : 15 mai 2003

ISSN : 0240-8910

Référence électronique

Pierre Lory, «Le traité de l'esprit saint de Rûzbehân de Shîrâz. Paris, Cerf, 2001, 362 p. », Abstracta Iranica [En ligne], Volume 24 | 2003, document 182, mis en ligne le 05 janvier 2010, consulté le 25 septembre 2020. URL : http://journals.openedition.org/abstractairanica/34555 ; DOI : https://doi.org/10.4000/ abstractairanica.34555

Ce document a été généré automatiquement le 25 septembre 2020.

Tous droits réservés 


\section{Le traité de l'esprit saint de Rûzbehân de Shîrâz. Paris, Cerf, 2001, 362 p.}

\section{Pierre Lory}

L'A. a entrepris ici de traduire et de commenter la Risālat al-quds de Rūzbehān Baqlī, traité sur l'itinéraire mystique et ce qu'on pourrait appeler improprement la «psychologie soufie ». Le texte de la traduction, établie à partir de l'édition du Dr. J. Nurbakhsh (1972) complétée par un manuscrit conservé à la BNF, est précédé d'une ample «Etude préliminaire » de 152 pages dans laquelle sont évoqués la vie et l'œuvre du grand mystique de Šĩrāz, et surtout sa démarche mystique et les principaux symboles dont il fait usage dans ce traité (et dans d'autres). L'ouvrage se termine par la traduction commentée d'un autre texte de Rūzbehān, le Lexique du soufisme, correspondant à la dernière partie du Šarḥ-e šathiyyāt. Le tout est riche et utile; il est simplement dommage que cette publication fasse suite à la traduction de la même Risālat al-quds par P. Ballanfat (L'itinéraire des esprits, suivi du Traité de la sainteté, Les Deux Océans, 2000 ; Abs. Ir. 23, c.r. $n^{\circ} 226$ ), bien que les deux perspectives soient sensiblement différentes.

\section{INDEX}

Thèmes : 8 . Soufisme 
AUTEURS

PIERRE LORY

EPHE - Paris 